\title{
47. SOME CLUES ABOUT THE NAPOLI AND MILANO MUD VOLCANOES FROM AN INTEGRATED LOG-CORE APPROACH ${ }^{1}$
}

\author{
María José Jurado-Rodríguez ${ }^{2}$ and Francisca Martínez-Ruiz ${ }^{3}$
}

\begin{abstract}
A full set of conventional logging data and Formation MicroScanner (FMS) data were acquired on the flanks of the Milano mud volcano and the Napoli mud volcano on the Mediterranean Ridge, and provide a complete and continuous record of the petrophysical and geological features of these structures. On the basis of the logging data, and of mineralogical and geochemical sample analyses, the composition, sedimentation, and internal sedimentary and structural features of the mud volcanoes were studied. Conventional logging data indicate composition and/or texture-related variations and indicate different sedimentation episodes. These changes are also recognizable on FMS images. Layered intervals are identified at different depths within both mud volcanoes. Most features that are recognized, possible bedding surfaces, dip to the west to northwest in the Milano mud volcano and to the north-northwest and north-northeast in the Napoli mud volcano. The dip of the beds is consistent with gravitational deposition and the present-day morphology of the Napoli mud volcano. The dip and strike of inferred bedding features at the Milano mud volcano suggest either the existence of a depositional slope and a source of gravitational flows to the east, or tilting of the bedding surfaces by subsidence after deposition. Steeply dipping planes $\left(>45^{\circ}\right)$ that dip north-northwest at Napoli are likely to represent fractures. These features are recognized as electrically resistive features indicating that they are filled with a nonconductive material, possibly either halite or gas. The results of core sample analysis indicate that diagenetic mineralogical transformations have not affected the mud volcano material, that the clay minerals are of detrital origin, and that Fe-Al-rich smectites are predominant.
\end{abstract}

\section{INTRODUCTION}

The Mediterranean Ridge mud volcanoes occur within the accretionary prism associated with ongoing subduction between the African and the Eurasian plates. This geological setting is characterized by thrusting and folding (Cita et al., 1996). Mud volcanism in the Mediterranean Ridge has been intensively studied in recent years (Cita et al., 1981; Cita and Camerlenghi, 1992; Limonov et al., 1994). Drilling >200 $\mathrm{m}$ into the Milano (conical) and Napoli (flat) structures was a major scientific achievement of Ocean Drilling Program (ODP) Leg 160. Successful drilling, coring, and logging were achieved at the Milano mud volcano (Site 970) and the active Napoli mud volcano (Site 971; Fig. 1; Emeis, Robertson, Richter, et al., 1996; Robertson et al., 1996). The surficial material extruded at the Milano and Napoli mud volcanoes, mainly a mud breccia with lithic clasts of centimetric size, was the main component recovered by drilling (Emeis, Robertson, Richter, et al., 1996; Robertson et al., 1996). At Site 970, layers of pelagic host sediments were also recovered (Emeis, Robertson, Richter, et al., 1996) and were interbedded with mud breccia. The layering indicates that the structure is a mud volcano, rather than a diapir (Emeis, Robertson, Richter, et al., 1996).

Holes were drilled at a depth of about $2000 \mathrm{~m}$ on the crestal areas and across the flanks of the mud volcanoes and onto adjacent deepsea sediments. One hole in the flank of each structure at each of the

${ }^{1}$ Robertson, A.H.F., Emeis, K.-C., Richter, C., and Camerlenghi, A. (Eds.), 1998. Proc. ODP, Sci. Results, 160: College Station, TX (Ocean Drilling Program).

${ }^{2}$ Geophysikalisches Institut, Universität Fridericiana Karlsruhe, Hertzstrasse 16, 76187 Karlsruhe, Federal Republic of Germany. Now at Instituto de Ciencias de la Tierra, Lluis Solé Sabarís s/n, 08028 Barcelona, Spain.mijurado@ija.csic.es

${ }^{3}$ Instituto de Ciencias de la Tierra CSIC-Universidad de Granada, Spain. two sites was geophysically logged (Holes 970A and 971B). Logging data constitute the most continuous record of the sedimentation at the Napoli and Milano mud volcanoes. Core recovery was poor $(25.1 \%$ in Hole 970A and $31.5 \%$ in Hole 971B).

The first results of Leg 160 (Robertson et al., 1996) shed light on many of the aspects of the history and evolution of the mud structures. The Milano mud volcano is at least 1.75 m.y. old and is now dormant. The Napoli mud volcano began before (or during) 1.5-1.2 $\mathrm{Ma}$ and is currently active. The age and character of the clasts are consistent with derivation from a relatively shallow underlying succession that includes Miocene sediments, although vitrinite reflectance data from organic matter indicate ranges of depth of mobilization from 4900 to $7500 \mathrm{~m}$ (Schulz et al. 1997). Pore fluids indicate the presence of halite of presumed latest Miocene age beneath the volcanoes. Hydrocarbon gas is venting from the crest of the Milano mud volcano. Methane hydrates (clathrates) are also inferred to exist beneath the crest of the Milano mud volcano (De Lange and Brumsack, Chapter 44, this volume).

Other hypotheses were also formulated based on the Leg 160 results. It was suggested that the extruding Miocene sediments clasts could have come either from the downgoing slab or from the overlying forearc basin, and that the higher hydrocarbons could have flowed laterally from great depths within the accretionary wedge (Robertson et al., 1996).

Some questions still remain and require more detailed work. The objective here is to provide a more complete picture of the mud volcanoes from a multidisciplinary approach, combining the analysis of conventional and Formation MicroScanner (FMS) log data, and mineralogical and geochemical analyses.

The main focus is the deeper parts of the mud structures, not reached by shallow coring, but satisfactorily recorded by logging 


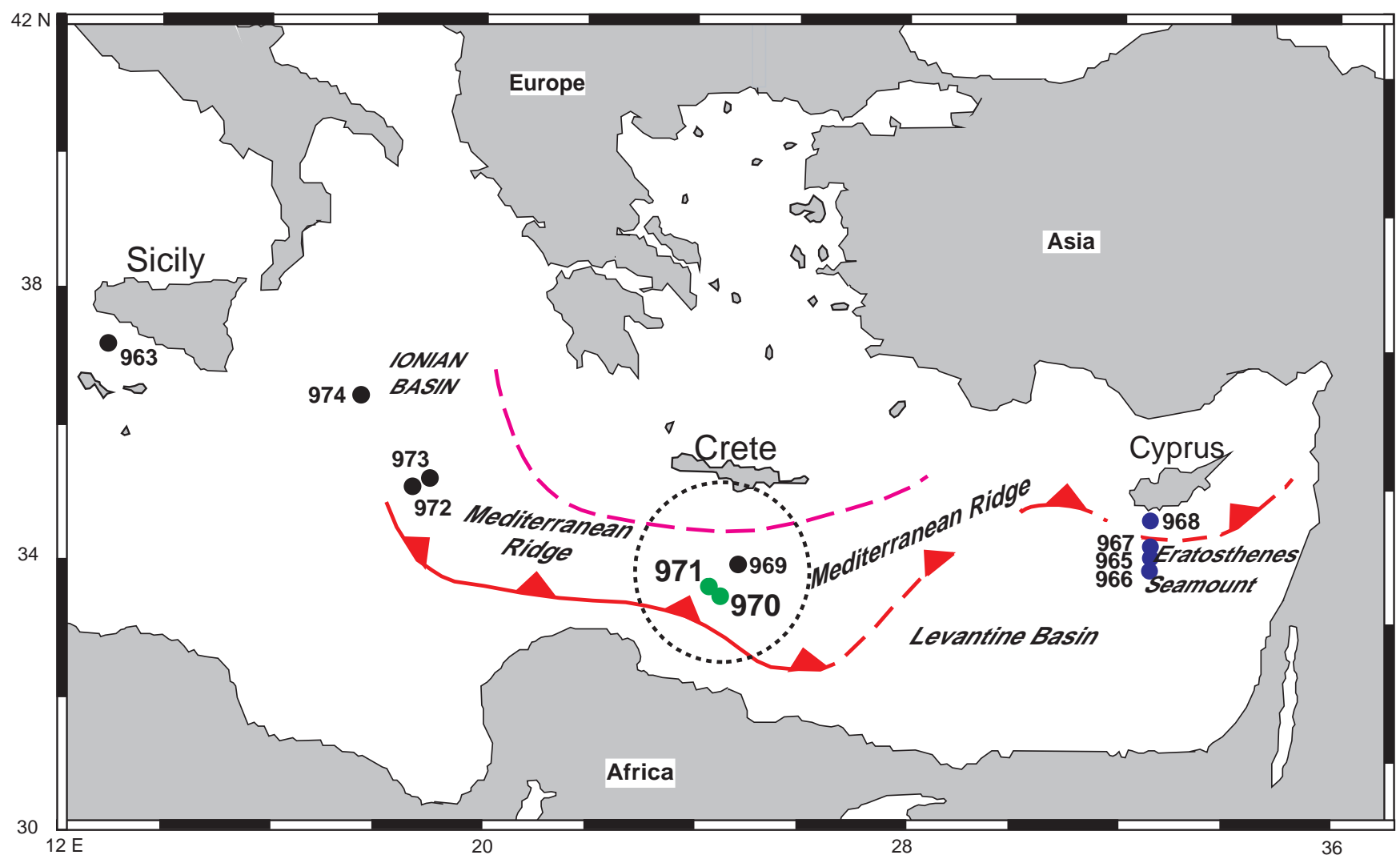

Figure 1. Location map for Leg 160. Sites 970 and 971 are located in the Milano and the Napoli mud volcanoes, respectively.

techniques. Geophysical logs provide a continuous record of the geophysical properties of the sediments, which are germane to geological interpretation. The FMS logging data provide, moreover, a computer-generated image of the borehole wall that allows the recognition of textures and structures. The integration of new results on provenance and diagenesis with the log analysis provides new clues about the origin and the evolution of the mud volcanoes. Some questions also arise regarding the role of fluid composition on the log response, and the mechanisms of the eruption of relatively dense material through rocks of lower density, which necessarily involves an important role of fluids and fluid pressures in the eruption process.

\section{METHODS}

Combined analysis of log and sample analyses allows us to calibrate the log response and provide constraints for interpretation of intervals where cores were not recovered. Specific methods were applied for the analysis and the interpretation of the logging data on one hand and for the study of mineral and chemical composition on the other hand.

\section{Log Analysis and Interpretation}

The logging data acquired at Sites 970 and 971 include conventional and FMS data. The ODP log database at Lamont-Doherty Earth Observatory (Borehole Research Group) provided shorebased processed and depth-shifted data.

The available spectral gamma-ray data consist of $\mathrm{U}, \mathrm{Th}, \mathrm{K}$ spectra, total gamma radiation (SGR), and computed gamma-ray log (CGR), including only Th and $\mathrm{K}$ radiation. Electrical logs include three measurements of the formation resistivity for different depths of investigation: shallow (SFL), medium (ILM), and deep (ILD). Other conventional logging data available are sonic (SONIC), highresolution density (RHOB), and high-resolution neutron (TNPH) logs. The quality of the spectral gamma-ray logs, reprocessed sonic, neutron, and resistivity logs available for Holes 970A and 971B is satisfactory for geological interpretation, in spite of the large-hole geometry that affected the acquisition. The qualitative interpretations presented in this study are based on this data set of conventional logs.

The quality of the FMS data obtained at Sites 970 and 971 is poor because of poor hole conditions, in particular at Hole 971B and for the lowermost section of Hole 970A. At Hole 971B the FMS tool could be run only over a short-depth interval (59.5-128 meters below seafloor [mbsf]) because of hole instability (Emeis, Robertson, Richter, et al., 1996). Borehole caving and the uneven shape of the borehole wall negatively affect the quality of the FMS data because they inhibit good pad-to-borehole wall contact. The borehole geometry is recorded by two perpendicular calipers of the four-arm FMS tool. The slim-hole FMS tool used during Leg 160 measures microresistivity in four pads. The coverage of the borehole wall depends on the hole geometry (diameter) and is generally $20 \%$ or less. The width of the strips of FMS images is proportional to the actual coverage of the borehole wall. Two passes of the FMS tool were run to increase the coverage that could be achieved if the tool orientation is different in each pass. At Hole 970A, both FMS passes were run with a slightly different orientation, providing a better coverage of the borehole wall. The hole with a diameter larger than the bit size shows a long, washed-out interval below $130 \mathrm{mbsf}$, where the borehole diameter exceeds the maximum aperture of both the FMS tool caliper and the density tool caliper. At Hole 971B, the short interval logged with the FMS tool is completely washed out. The effects of these poor hole 
conditions on the images are easily recognizable by poor-quality and low-definition images. In spite of the overall poor pad contact, processing of the data has allowed us to enhance the features recorded by the FMS tool.

All procedures, from the acquisition of electrical microresistivity using the FMS tool to the interpretation of the images, were done according to standard processing methods (Ekstrom et al., 1987; Bourke, 1989; Harker et al., 1990; Rider, 1996). Processing of the FMS data, including static and dynamic normalization, was performed to obtain enhanced images. The static normalization provided an image in which the actual contrast in resistivities is preserved throughout the interval chosen (in this study, the complete hole run). The dynamic normalization processing provided better contrast between the features recorded by the FMS microresistivity sensors; however, the resistivity and the color image are not representative of the actual resistivity contrast. Both processed images have been used in the interpretation; the figures included in this study correspond to static normalized FMS images. The interpretation was also performed on both pass 1 and pass 2 of each hole to allow better coverage of the borehole wall.

The main objectives of the FMS interpretation were the observation of sedimentary textures and structures and the measurement of dip and azimuth of planar features. Horizontal features appear flat on the FMS images, whereas dipping events appear as sine waves. The amplitude of the sine wave gives the dip of the plane, and the dip azimuth is calculated at the low point of the wave. The FMS files contain the information necessary to calculate the orientation of the features interpreted. Fitting of the sine waves was achieved interactively using a workstation. More details on the FMS processing and interpretation procedures can be found in Jurado and Brudy (Chapter 41, this volume).

\section{Sample Analyses}

\section{$X$-ray Diffraction}

Samples were dried at room temperature and ground in an agate mortar to $<2 \mathrm{~mm}$ in size. A homogeneous, representative part was ground to $<0.0053 \mathrm{~mm}$ and this was used for the mineralogical study (bulk mineralogy). Samples were packed in Al sample holders for Xray diffraction (XRD). Another portion was used for clay mineral studies after the carbonate fraction was removed by acetic acid, starting the reaction at a very low acid concentration $(0.1 \mathrm{~N})$, and increasing this concentration up to $1 \mathrm{~N}$. The $<2 \mu \mathrm{m}$ was separated by centrifuging at $9000 \mathrm{rpm}$ during $1.5 \mathrm{~min}$. The clay fraction was smeared onto glass slides for XRD. Separation of the clay fraction and preparation of the samples for diffractometric studies were performed following the international recommendations compiled by Kisch (1991). XRD diffractograms were performed using a Phillips PW 1710 diffractometer with $\mathrm{Cu}-\mathrm{K} \alpha$ radiation and automatic silt. Scans were run from $2^{\circ}$ to $64^{\circ} 2 \theta$ for bulk sample diffractograms and clay preparation without any treatment, and from $2^{\circ}$ to $30^{\circ} 2 \theta$ for glycolated and heated clay mineral samples. The reflecting factors calculated for this equipment and its instrumental conditions were the following: (1) for powder diffractograms: phyllosilicates, 0.09; quartz, 1.43; calcite, 1.05; feldspar, 1.03; and (2) for oriented sample diffractograms: illite, 0.36; chlorite, kaolinite, 0.98; mixed-layer illite/smectite, 0.65 . Diffractograms were visually interpreted with the help of a computerized search.

Semiquantitative analyses were performed utilizing the integrated peak area with the aid of a computer program. The clay mineral amount was estimated on the diffractograms of the glycolated samples. The 10 - $\AA$ peak was used for illite. The 7 - $\AA$ peak gives the total amount of chlorite + kaolinite, using the peaks at $3.54 \AA$ and $3.58 \AA$, respectively, to differentiate and identify the presence of these minerals. The 17-Å peak was used for smectites. The estimate semiquantitative analysis error for bulk mineralogy absolute values is $\pm 5 \%$, for clay mineral amount, ranging from $5 \%$ to $10 \%$.

\section{Transmission Electron Microscopy}

Quantitative geochemical microanalyses of the smectites were obtained by transmission electron microscopy (TEM) using a Phillips CM-20 (Instrumental Services of the University of Granada, Spain) equipped with an EDAX microanalysis system. Quantitative analy-

Table 1. Bulk mineralogy and clay minerals of the studied samples at Site 970A.

\begin{tabular}{|c|c|c|c|c|c|c|c|c|c|}
\hline $\begin{array}{l}\text { Core, section, } \\
\text { interval }(\mathrm{cm})\end{array}$ & $\begin{array}{l}\text { Depth } \\
\text { (mbsf) }\end{array}$ & Calcite & Clays & Quartz & Dolomite & Feldspar & Smectite & Illite & Kaolinite \\
\hline \multicolumn{10}{|l|}{ 160-970A- } \\
\hline $8 \mathrm{X}-\mathrm{CC}, 24-26$ & 56.94 & 64 & 21 & 12 & $<5$ & $?$ & 68 & 7 & 25 \\
\hline $9 \mathrm{X}-1,30-32$ & 66.60 & 29 & 46 & 20 & $<5$ & $<5$ & 69 & 7 & 23 \\
\hline $10 X-1,19-21$ & 76.19 & 24 & 44 & 22 & $<5$ & 5 & 75 & 6 & 20 \\
\hline 11X-CC, $42-44$ & 86.12 & $<5$ & 13 & 4 & 74 & $?$ & 29 & 50 & 21 \\
\hline $12 \mathrm{X}-\mathrm{CC}, 4-6$ & 95.44 & 29 & 35 & 31 & $<5$ & $<5$ & 82 & 6 & 12 \\
\hline $13 \mathrm{X}-1,43-45$ & 105.53 & 29 & 20 & 43 & $<5$ & 6 & 74 & $<5$ & 22 \\
\hline $14 X-1,48-50$ & 115.28 & 67 & 25 & 5 & $<5$ & $?$ & 71 & 9 & 20 \\
\hline $15 X-1,7-9$ & 124.47 & 38 & 34 & 18 & 8 & $<\dot{5}$ & 68 & 21 & 12 \\
\hline $15 \mathrm{X}-2,123-125$ & 127.02 & 56 & 25 & 14 & $<5$ & $<5$ & 71 & 11 & 18 \\
\hline $16 \mathrm{X}-1,98-100$ & 134.98 & 51 & 31 & 11 & 5 & $<5$ & 23 & 35 & 42 \\
\hline $16 \mathrm{X}-2,90-92$ & 136.40 & 56 & 30 & 8 & $<5$ & $<5$ & 38 & 21 & 41 \\
\hline $16 X-3,40-42$ & 137.40 & 70 & 20 & 7 & $<5$ & $<5$ & 35 & 39 & 26 \\
\hline $17 \mathrm{X}-1,80-84$ & 144.40 & 55 & 23 & 12 & 7 & $<5$ & 27 & 42 & 31 \\
\hline $17 \mathrm{X}-2,30-34$ & 145.40 & 37 & 38 & 12 & 8 & $<5$ & 20 & 45 & 36 \\
\hline $17 X-3,67-71$ & 147.27 & 68 & 17 & 6 & 8 & $<5$ & 21 & 55 & 24 \\
\hline $18 \mathrm{X}-1,85-89$ & 154.05 & 47 & 21 & 18 & 8 & 6 & 75 & 6 & 18 \\
\hline $18 X-2,67-71$ & 155.17 & 43 & 23 & 17 & 16 & $<5$ & 54 & 29 & 17 \\
\hline $18 \mathrm{X}-3,36-40$ & 156.36 & 28 & 43 & 17 & 7 & $<5$ & 70 & 8 & 22 \\
\hline $19 \mathrm{X}-1,102-106$ & 163.82 & 22 & 38 & 26 & 9 & 5 & 80 & 5 & 15 \\
\hline $19 X-2,41-45$ & 164.71 & 15 & 41 & 31 & 10 & $<5$ & 82 & $<5$ & 17 \\
\hline $19 X-3,58-62$ & 166.26 & 20 & 51 & 21 & 7 & $<5$ & 84 & 6 & 10 \\
\hline $20 \mathrm{X}-1,93-97$ & 173.43 & 17 & 47 & 23 & 11 & $<5$ & 84 & $<5$ & 12 \\
\hline $20 \mathrm{X}-2,67-71$ & 174.67 & 20 & 47 & 22 & 2 & 9 & 78 & 6 & 16 \\
\hline $21 X-1,56-60$ & 182.66 & 31 & 39 & 15 & 13 & $<5$ & 76 & $<5$ & 20 \\
\hline $21 \mathrm{X}-2,122-126$ & 184.82 & 26 & 37 & 15 & 17 & 5 & 69 & 11 & 20 \\
\hline $21 X-3,17-21$ & 185.27 & 29 & 31 & 22 & 12 & 6 & 69 & 9 & 22 \\
\hline $22 X-1,52-56$ & 192.22 & 27 & 53 & 10 & 7 & $<5$ & 73 & 5 & 21 \\
\hline $22 \mathrm{X}-1,120-124$ & 192.90 & 67 & 20 & 6 & 6 & $<5$ & 21 & 48 & 30 \\
\hline $22 \mathrm{X}-2,122-126$ & 194.42 & 56 & 25 & 11 & 7 & $<5$ & 24 & 42 & 34 \\
\hline $22 \mathrm{X}-3,144-148$ & 196.14 & 86 & $<5$ & 8 & $<5$ & $<5$ & 8 & 55 & 38 \\
\hline $22 \mathrm{X}-4,96-100$ & 197.16 & 62 & 23 & 10 & $<5$ & $<5$ & 19 & 54 & 27 \\
\hline
\end{tabular}

Note: ? = undetermined. 
Table 2. Bulk mineralogy and clay minerals of the studied samples at Site 971B.

\begin{tabular}{|c|c|c|c|c|c|c|c|c|c|c|}
\hline $\begin{array}{l}\text { Core, section, } \\
\text { interval }(\mathrm{cm})\end{array}$ & $\begin{array}{l}\text { Depth } \\
\text { (mbsf) }\end{array}$ & Calcite & Clays & Quartz & Dolomite & Feldspar & Halite & Smectite & Illite & Kaolinite \\
\hline \multicolumn{11}{|l|}{ 160-971B- } \\
\hline $8 X-1,30-35$ & 59.20 & 25 & 38 & 16 & 8 & $<5$ & 11 & 74 & $<5$ & 22 \\
\hline $9 X-1,42-46$ & 69.02 & 21 & 54 & 13 & $<5$ & $<5$ & 7 & 77 & 5 & 18 \\
\hline $12 X-1,11-15$ & 97.61 & 22 & 40 & 24 & $<5$ & $<5$ & 9 & 79 & $<5$ & 17 \\
\hline $12 \mathrm{X}-\mathrm{CC}, 9-13$ & 99.17 & 22 & 64 & 5 & $<5$ & ? & 6 & 64 & 10 & 27 \\
\hline $13 \mathrm{X}-1,16-20$ & 107.16 & 20 & 39 & 27 & $<5$ & $<\dot{5}$ & 10 & 80 & $<5$ & 19 \\
\hline $13 X-2,20-22$ & 108.80 & 23 & 42 & 24 & $<5$ & $<<5$ & 7 & 82 & $<5$ & 15 \\
\hline $14 \mathrm{X}-1,36-40$ & 117.06 & 22 & 29 & 23 & $<5$ & 11 & 11 & 82 & $<5$ & 16 \\
\hline $14 \mathrm{X}-2,36-40$ & 118.56 & 21 & 51 & 15 & $<5$ & $<5$ & 9 & 81 & $<5$ & 24 \\
\hline 14X-CC, $14-18$ & 119.42 & 24 & 30 & 25 & 6 & $<5$ & 12 & 75 & $<5$ & 20 \\
\hline $15 X-1,10-14$ & 126.40 & 19 & 49 & 15 & $<5$ & 5 & 9 & 77 & $<5$ & 16 \\
\hline $15 \mathrm{X}-\mathrm{CC}, 10-14$ & 127.56 & 23 & 35 & 23 & $<5$ & $<5$ & 13 & 78 & 7 & 10 \\
\hline $16 \mathrm{X}-1,10-14$ & 136.10 & 16 & 50 & 18 & $<5$ & $<5$ & 11 & 86 & $<5$ & 21 \\
\hline $16 \mathrm{X}-2,10-14$ & 137.60 & 5 & 40 & 24 & 18 & 5 & 14 & 73 & 6 & 16 \\
\hline $16 X-3,4-8$ & 138.98 & 40 & 26 & 13 & $<5$ & $<5$ & 17 & 78 & 6 & 16 \\
\hline $16 \mathrm{X}-\mathrm{CC}, 4-8$ & 140.17 & 22 & 52 & 11 & $<5$ & $<5$ & 11 & 79 & 5 & 18 \\
\hline $17 X-1,4-8$ & 145.64 & 30 & 38 & 15 & $<5$ & $<5$ & 14 & 81 & $<5$ & 15 \\
\hline $17 \mathrm{X}-2,4-8$ & 147.14 & 11 & 60 & 15 & ? & $<5$ & 12 & 82 & $<5$ & 11 \\
\hline $17 \mathrm{X}-\mathrm{CC}, 4-8$ & 148.97 & 64 & $<5$ & 13 & 8 & $<5$ & 8 & 84 & 5 & 14 \\
\hline $18 \mathrm{X}-\mathrm{CC}, 4-8$ & 155.24 & 22 & 45 & 18 & $<5$ & $<5$ & 12 & 82 & $<5$ & 15 \\
\hline $19 X-1,4-8$ & 164.94 & 21 & 49 & 17 & $<5$ & $<5$ & 8 & 79 & 6 & 17 \\
\hline $19 X-2,4-8$ & 166.44 & 20 & 51 & 14 & $<5$ & 5 & 7 & 74 & 8 & 14 \\
\hline $19 X-3,4-8$ & 167.94 & 26 & 33 & 29 & $<5$ & $<5$ & 10 & 84 & $<5$ & 20 \\
\hline $19 X-4,4-8$ & 169.13 & 22 & 39 & 24 & $<5$ & $<5$ & 8 & 75 & 5 & 17 \\
\hline $19 X-5,4-8$ & 170.63 & 22 & 48 & 18 & $<5$ & $<5$ & 8 & 76 & 5 & 19 \\
\hline
\end{tabular}

Note: ? = undetermined

Table 3. Transmission Electron Microscopy (TEM) microanalyses of smectites at Holes 970A and 971B.

\begin{tabular}{|c|c|c|c|c|c|c|c|c|c|c|}
\hline $\begin{array}{l}\text { Hole, core, section, interval } \\
\qquad(\mathrm{cm})\end{array}$ & $\begin{array}{l}\text { Depth } \\
(\mathrm{mbsf})\end{array}$ & $\mathrm{Si}$ & Al IV & $\mathrm{Al} \mathrm{VI}$ & $\mathrm{Fe}$ & Mg. & S oct. & $\mathrm{K}$ & $\mathrm{Ca}$ & $\mathrm{Na}$ \\
\hline \multicolumn{11}{|l|}{ 160-970A- } \\
\hline \multirow[t]{6}{*}{$9 \mathrm{X}-1,30-32$} & 66.60 & 3.78 & 0.22 & 1.80 & 0.32 & 0.10 & 2.22 & 0.03 & 0.05 & - \\
\hline & & 3.71 & 0.29 & 1.69 & 0.29 & 0.12 & 2.10 & 0.03 & 0.04 & - \\
\hline & & 3.87 & 0.13 & 1.40 & 0.36 & 0.33 & 2.09 & 0.10 & 0.04 & - \\
\hline & & 3.30 & 0.70 & 1.77 & 0.23 & 0.15 & 2.15 & 0.28 & 0.00 & - \\
\hline & & 3.24 & 0.76 & 1.10 & 0.65 & 0.59 & 2.34 & 0.11 & 0.02 & 0.02 \\
\hline & & 3.81 & 0.19 & 1.35 & 0.48 & 0.27 & 2.10 & 0.07 & 0.03 & - \\
\hline \multirow[t]{3}{*}{$15 X-2,123-125$} & 127.02 & 3.75 & 0.25 & 1.39 & 0.27 & 0.52 & 2.18 & 0.14 & 0.01 & 0.06 \\
\hline & & 3.32 & 0.68 & 1.59 & 0.28 & 0.31 & 2.18 & 0.17 & - & - \\
\hline & & 3.36 & 0.64 & 1.96 & 0.15 & 0.12 & 2.23 & 0.05 & - & - \\
\hline \multirow[t]{4}{*}{$18 X-2,67-71$} & 155.17 & 3.50 & 0.50 & 1.50 & 0.35 & 0.40 & 2.25 & 0.10 & - & - \\
\hline & & 3.78 & 0.22 & 1.16 & 0.51 & 0.50 & 2.17 & 0.17 & - & - \\
\hline & & 3.55 & 0.45 & 1.35 & 0.36 & 0.44 & 2.15 & 0.32 & 0.10 & - \\
\hline & & 3.53 & 0.47 & 1.68 & 0.16 & 0.33 & 2.17 & 0.23 & - & - \\
\hline \multirow[t]{5}{*}{$20 X-2,67-71$} & 174.67 & 3.48 & 0.52 & 1.52 & 0.36 & 0.34 & 2.22 & 0.08 & 0.08 & - \\
\hline & & 3.57 & 0.43 & 1.38 & 0.45 & 0.32 & 2.15 & 0.11 & 0.10 & - \\
\hline & & 3.70 & 0.30 & 1.22 & 0.56 & 0.32 & 2.10 & 0.17 & 0.06 & - \\
\hline & & 3.62 & 0.38 & 1.36 & 0.23 & 0.61 & 2.20 & 0.32 & - & 0.10 \\
\hline & & 3.50 & 0.50 & 1.70 & 0.11 & 0.21 & 2.02 & 0.37 & - & 0.18 \\
\hline $22 X-2,122-126$ & 194.42 & 3.55 & 0.45 & 1.35 & 0.36 & 0.44 & 2.15 & 0.32 & 0.10 & - \\
\hline \multicolumn{11}{|l|}{ 160-971B- } \\
\hline \multirow[t]{6}{*}{$9 \mathrm{X}-1,42-46$} & 69.02 & 3.78 & 0.22 & 1.80 & 0.32 & 0.10 & 2.22 & 0.03 & 0.05 & - \\
\hline & & 3.71 & 0.29 & 1.69 & 0.29 & 0.12 & 2.10 & 0.03 & 0.04 & - \\
\hline & & 3.70 & 0.30 & 1.35 & 0.46 & 0.40 & 2.21 & 0.13 & - & 0.12 \\
\hline & & 3.28 & 0.72 & 1.34 & 0.42 & 0.58 & 2.34 & 0.10 & 0.03 & 0.05 \\
\hline & & 3.52 & 0.42 & 1.62 & 0.33 & 0.23 & 2.18 & 0.08 & - & 0.09 \\
\hline & & 3.52 & 0.48 & 1.60 & 0.26 & 0.37 & 2.23 & 0.04 & - & 0.01 \\
\hline \multirow{5}{*}{$16 X-2,10-14$} & 137.60 & 3.65 & 0.35 & 1.14 & 0.55 & 0.36 & 2.05 & 0.12 & - & - \\
\hline & & 3.58 & 0.42 & 1.35 & 0.41 & 0.38 & 2.14 & 0.09 & - & 0.12 \\
\hline & & 3.65 & 0.35 & 1.64 & 0.20 & 0.34 & 2.18 & 0.21 & - & - \\
\hline & & 3.69 & 0.31 & 1.41 & 0.40 & 0.29 & 2.10 & 0.14 & - & 0.12 \\
\hline & & 3.55 & 0.45 & 1.28 & 0.51 & 0.46 & 2.25 & 0.09 & - & - \\
\hline \multirow[t]{4}{*}{$19 X-3,4-8$} & 167.94 & 3.52 & 0.48 & 1.23 & 0.60 & 0.32 & 2.15 & 0.20 & - & 0.19 \\
\hline & & 3.48 & 0.52 & 1.23 & 0.35 & 0.76 & 2.34 & 0.09 & - & 0.13 \\
\hline & & 3.53 & 0.47 & 1.54 & 0.35 & 0.22 & 2.11 & 0.14 & - & 0.18 \\
\hline & & 3.54 & 0.46 & 1.29 & 0.45 & 0.26 & 2.00 & 0.20 & - & 0.26 \\
\hline
\end{tabular}

Note: $-=$ no data

ses were obtained in scanning TEM (STEM) mode only from the edges using a 70- $\AA$ beam diameter and $200 \times 1000 \AA$ A scanning area. To avoid problems of alkali loss, we used a short counting time (30 s), which gives a better reproducibility for alkali contents (Nieto et al, 1996). The smectite formulae were normalized to 11 oxygens. The results of sample analyses are summarized in Tables 1-3.

\section{MILANO MUD VOLCANO Conventional Logs}

The most obvious feature recognizable on the conventional logs for Hole 970A is a sharp change in log properties above and below 133.5 mbsf (Figs. 2, 3). Density, acoustic velocity, and electrical re- 


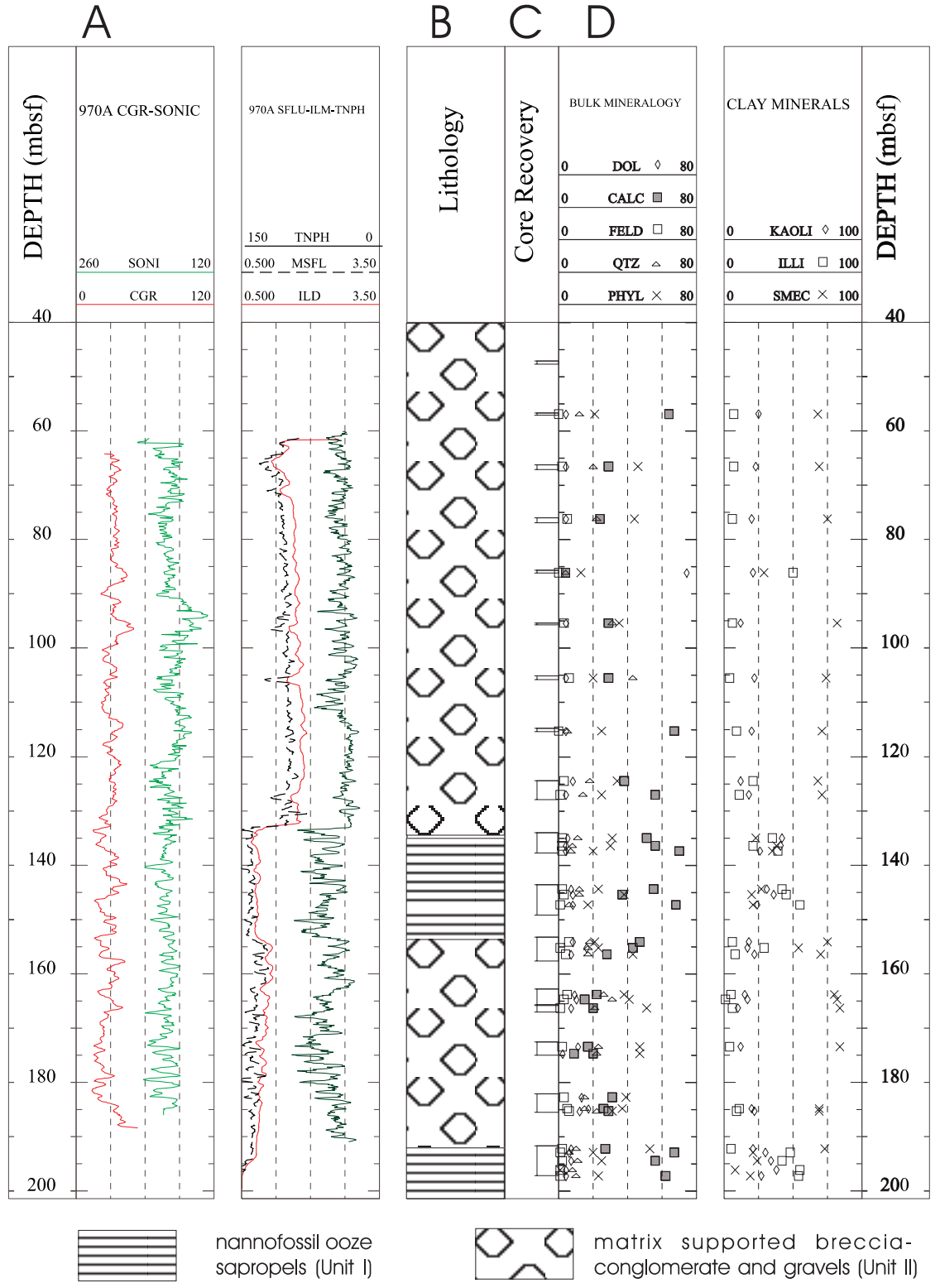

Figure 2. A. Conventional logs, Hole 970A: sonic log (SONI), in $\mu \mathrm{s} / \mathrm{ft}$, computed gamma-ray $\log (\mathrm{CGR})$ in API units, neutron $\log (\mathrm{TNPH})$ in porosity units, microspherically focused $\log$ (MSFL) in $\Omega \mathrm{m}$, and deep induction resistivity $\log$ (ILD) in $\Omega \mathrm{m}$. B. Corereconstructed lithology column. C. Core recovery. D. Sample analytical results for bulk and clay mineralogy: carbonate content (CALC), quartz (QTZ), clay minerals (PHYL), feldspar (FELD), kaolinite (KAOLI), micaceous minerals (ILLI), and smectites (SMEC). sistivity show a reversal below $133.5 \mathrm{mbsf}$. This change is coincident with the boundary between mud breccia sediments and layered nannofossil oozes, and is also evident on FMS images. Given the low core recovery, the interpretation of the log data allow a precise recognition of the boundary between the mud breccia and the layered nannofossil ooze. Intervals of slightly different natural gamma-ray, resistivity, and density log properties observed within the mud breccia Unit II (Fig. 3) probably reflect episodicity in sedimentation of the mud breccia, and corresponding changes in textures, which are also recognizable on FMS images. A change in conventional log values (Fig. 3) at 152.5 mbsf indicates a change in the composition of the sediments at the boundary between the nannofossil ooze (Unit I) and the polymictic gravels (Unit II).

\section{Sample Analyses}

The samples analyzed for Site 970 (Tables 1, 3; Fig. 2) correspond to lithostratigraphic Unit I (nannofossil clay, nannofossil ooze clay, and nannofossil ooze), and also to the clay matrix of Unit II (Emeis, Robertson, Richter, et al., 1996).

The results obtained indicate that these sediments are mainly composed of clay minerals, calcite, quartz, minor proportions of feldspar and dolomite, and traces of pyrite; in some samples from Unit II traces of gypsum were also detected. Proportions of the different components are slightly different in both units (Fig. 2; Table 1). Unit I is characterized by a higher content in calcite, and a lower content of quartz and clay minerals than Unit II. Clay mineral assemblages are similar in both units, being mainly composed of smectites, illite and kaolinite; traces of chlorite were also detected in Unit I. However, clay mineral percentages are also different in both units. Unit I, which represents an interval of pelagic sediments, shows lower smectite contents and higher illite contents. Transmission microscopic microanalyses show the presence of broken fibers of palygorskite and sepiolite in both units, based both on chemical composition and TEM morphology. TEM microanalysis reveals that the illites correspond to detrital micas. The chemical composition of the smectites is summa- 
Figure 3. A. Conventional logs, Hole 970A: spectral total gamma radiation (SGR) in API units, neutron log (HTNP) in porosity units, and deep induction resistivity $\log$ (ILD) in $\Omega \mathrm{m}$. B. FMS-measured dips tadpole plot $\left({ }^{\circ}\right)$. C. Core recovery and core-reconstructed lithology column. D. Schmidt projection of the interpreted dips (upper hemisphere). The dotted lines across the conventional logs indicate the depths at which significant changes in log values occur.
A

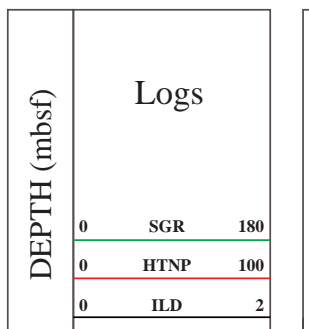

B

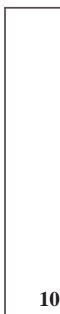

\begin{tabular}{|} 
\\
\hline \\
50
\end{tabular}

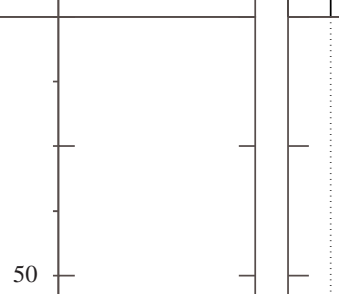
$2030 \quad 40 \quad 609$
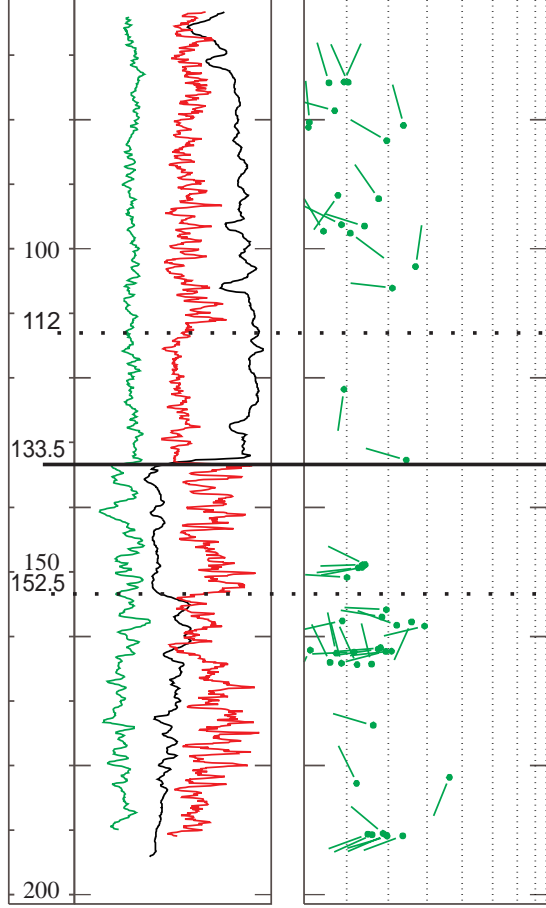

nannofossil ooze sapropels (Unit I)
C

ڤేँ

D
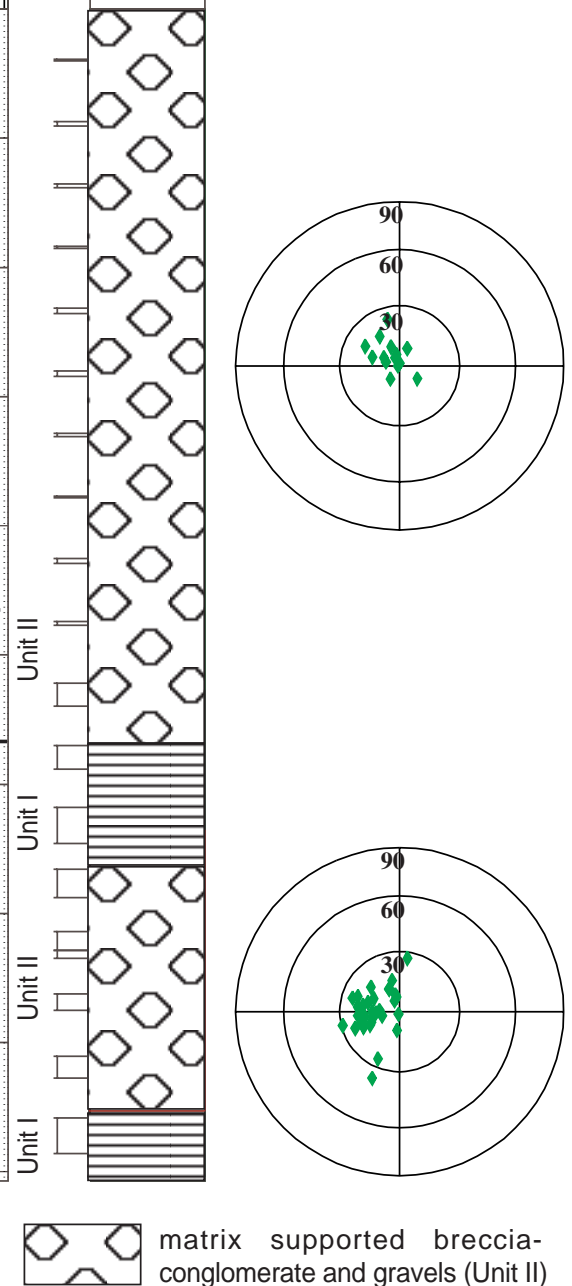

matrix supported brecciaconglomerate and gravels (Unit II) rized in Table 3. They correspond to Al-rich beidellites of the nontronite-beidellite series and show typical fleecy morphologies.

\section{FMS Interpretation}

The FMS images provide information about internal textures and structures. The inferred orientation of bedding surfaces in Hole 970A is shown in Figure 3 and Table 4. Figure 4 includes some examples of FMS images obtained from Hole 970A FMS passes 1 and 2.

The preferred azimuth of the planes interpreted as bedding features dip to the west, northwest and southwest. Layered sediments of Unit I and Unit II show similar patterns. Most planes are gently dipping $\left(0^{\circ}-20^{\circ}\right)$.

The lowermost levels recorded with the FMS tool at Hole 970A correspond to layered sediments with a pebbly appearance. The fea- tures in the lower part of the image suggest the existence of pebbly, graded deposits (193.5-195 mbsf). Well-layered sediments are observed in the upper part of the image in Figure 4A, and dips could be measured (Fig. 4B; Table 4). Comparison of the limited core recovery with the FMS images indicates that the top of the layered nannofossil ooze in Unit I is probably below $195 \mathrm{mbsf}$, deeper than initially assigned (Figs. 2, 3).

Higher in the succession in Hole 970A, pebbly intervals again alternate also further up with layered intervals (Fig. 4B), within the polymictic gravel Subunit IIC (Emeis, Robertson, Richter, et al., 1996). The uppermost part of this interval, Subunit IIC, was described as a polymictic breccia, (Emeis, Robertson, Richter, et al., 1996), and displays clear layering on FMS images.

The quality of the images within nannofossil oozes of Unit I is poor because of bad borehole conditions. However, bedding features 
Table 4. Hole 970A: azimuth and dip of the planes interpreted on FMS images.

\begin{tabular}{|c|c|c|c|}
\hline \multirow[t]{27}{*}{$\begin{array}{l}\text { Hole } 970 \mathrm{~A} \\
\text { Pass 1: }\end{array}$} & $\begin{array}{l}\text { Depth } \\
\text { (mbsf) }\end{array}$ & $\begin{array}{c}\text { Azimuth } \\
\left({ }^{\circ}\right)\end{array}$ & $\begin{array}{c}\text { Dip } \\
\left({ }^{\circ}\right)\end{array}$ \\
\hline & 74.23 & 335.2 & 10.3 \\
\hline & $\begin{array}{l}74.29 \\
\text {. }\end{array}$ & 343.4 & 5.8 \\
\hline & 81.20 & 270.7 & 1 \\
\hline & 96.48 & 287.5 & 14.2 \\
\hline & 106.07 & 276.5 & 21 \\
\hline & 121.76 & 188.4 & 9.3 \\
\hline & 132.68 & 286.2 & 24.5 \\
\hline & 148.91 & 296.3 & 14.4 \\
\hline & 149.32 & 259.4 & 13.6 \\
\hline & 150.86 & 273.5 & 10 \\
\hline & 155.86 & 272.9 & 19.5 \\
\hline & 157.59 & 257 & 8.9 \\
\hline & 157.75 & 204.7 & 25.9 \\
\hline & 158.26 & 289.8 & 22.1 \\
\hline & 158.39 & 256.4 & 29.3 \\
\hline & 161.75 & 265 & 18.1 \\
\hline & 162.14 & 206.9 & 1.4 \\
\hline & 162.29 & 264.3 & 20.8 \\
\hline & 164.15 & 345.7 & 8.7 \\
\hline & 164.28 & 346.3 & 15.9 \\
\hline & 164.36 & 335 & 12.4 \\
\hline & 173.74 & 286.2 & 16.3 \\
\hline & 181.83 & 202.5 & 36.2 \\
\hline & 190.51 & 310.3 & 18.7 \\
\hline & 190.69 & 245.5 & 16 \\
\hline & 190.87 & 249.4 & 23.6 \\
\hline \multirow{25}{*}{$\begin{array}{l}\text { Hole 970A } \\
\text { Pass 2: }\end{array}$} & Depth & Azimuth & Dip \\
\hline & (mbsf) & $\left({ }^{\circ}\right)$ & $\left({ }^{\circ}\right)$ \\
\hline & 74.15 & 23.6 & 9.3 \\
\hline & 78.62 & 285.3 & 7.1 \\
\hline & 80.41 & 355.3 & 1.2 \\
\hline & 80.88 & 345.2 & 23.8 \\
\hline & 83.24 & 299.7 & 19.6 \\
\hline & 91.70 & 214.9 & 7.9 \\
\hline & 92.26 & 325.6 & 17.6 \\
\hline & 96.26 & 296.8 & 8.7 \\
\hline & 97.28 & 329.5 & 4.5 \\
\hline & 97.59 & 126.6 & 10.8 \\
\hline & 102.75 & 8.3 & 26.9 \\
\hline & 148.93 & 268.5 & 13.7 \\
\hline & 149.39 & 263.8 & 12.7 \\
\hline & 157.01 & 279.8 & 18.4 \\
\hline & 161.96 & 261.9 & 17.5 \\
\hline & 162.33 & 255.8 & 19.4 \\
\hline & 162.43 & 267.6 & 11.7 \\
\hline & 162.62 & 348.2 & 7.5 \\
\hline & 164.01 & 334.3 & 6 \\
\hline & 182.75 & 334.4 & 12.3 \\
\hline & 190.613 & 249.3 & 15 \\
\hline & 190.769 & 246.8 & 19.5 \\
\hline & 190.916 & 253.3 & 19.7 \\
\hline
\end{tabular}

can be distinguished (Fig. 4C). Utilizing FMS images and conventional logs, the boundary between nannofossil ooze in Unit I and polymictic gravel in Unit II is placed at 152.5 mbsf (Fig. 3).

The FMS images reveal facies changes at the boundary between conductive, underlying nannofossil ooze sediments, and resistive mud breccia at the base of Unit II. This is observed in pass 1 images and even better so in pass 2 images (Fig. 4C). The base of the mud breccia in the upper section of Unit II is revealed on the FMS images as an interval of higher resistivity in which the shape of clasts (flattened in the images because of the vertical scaling) is recognizable (Fig. 4C). The boundary between Unit II and Unit I is characterized by increased resistivity relative to the overlying and the underlying levels (Fig. 4C). No significant change in composition or texture can be recognized for the interval in which these changes occur, based on either the other conventional logs or the sample analysis (Table 1; Fig. 2). One possible interpretation is that increased resistivity observed on the FMS images is related to changes in texture or diagenesis (cementation?). A possible role of fluid composition should be also considered. In fact, the salinity profile shows an inflection point towards an increase in salinity recognizable at 135.35 mbsf within Subunit IIC (Emeis, Robertson, Richter, et al., 1996).

The images obtained for different depths within the upper section of the matrix-supported breccia/conglomerate of Unit II (Figs. 3, 4C, D) reveal an alternation in clast-matrix abundance, clast size, and probably clast composition). The largest clast size observed on the FMS images (about $55 \mathrm{~cm}$ ) is within the lowermost interval of Unit I (112-133.5 mbsf; Fig. 4C). Indications of heterogeneity and episodicity recognized on conventional logs (Fig. 3; Emeis, Robertson, Richter, et al., 1996) can be interpreted in terms of successive depositional events within Unit II. The analysis of sample does not indicate any marked change in the matrix of the breccias (Fig. 2).

\section{NAPOLI MUD VOLCANO Conventional Logs}

Borehole conditions inhibited successful and complete logging in Hole 971B (Emeis, Robertson, Richter, et al., 1996). Only one complete run was achieved from 170 mbsf upwards. Spectral gamma-ray, sonic, and resistivity logs were recorded with the induction-sonic tool combination during the first run. During the second logging run, it was only possible to log from 126 mbsf upward (neutron, density $\operatorname{logs}$ ) and the same occurred when using the FMS tool.

When examined carefully, the conventional logs do indicate subtle changes that were not identifiable in the cores (Emeis, Robertson, Richter, et al., 1996; Figs. 5, 6). Four sections of slightly differing log properties can be recognized: from the uppermost logged interval to 99 mbsf; 99 to 122.8 mbsf; 122.8 to 148 mbsf; and 148 to the maximum depth recorded. The uppermost intervals display slightly different dip patterns (Fig. 6; Table 5), and show clear boundaries on the FMS data (Fig. 7A). The first, second, and fourth depth intervals are characterized on the conventional logs (Fig. 6) by a rather homogeneous response, which contrasts with the interval from 122.8 to 148 mbsf, within which variations in log properties suggest episodicity.

The resistivity for the upper interval (to $122.8 \mathrm{mbsf}$ ) of Log Unit I is higher than that of the underlying interval. A slightly increasing trend in the values of the acoustic velocity and electrical resistivity, observed between 99 and 122.8 mbsf (Figs. 5, 6), can be interpreted in terms of compaction or increasing grain size (fining-upwards sequence). The first hypothesis is preferred: the gamma-ray log does not mirror this trend, as it should commonly in the case of graded sequences. Within the interval from 122.8 to $148 \mathrm{mbsf}$, a rather homogeneous section of higher radioactivity, slightly higher resistivity, and higher sonic velocity can be recognized. At least four intervals of slightly differing texture and/or composition may be present (Fig. 6). According to the core lithostratigraphy description, this interval corresponds to mud breccia sediments, and the log features would then be indicative of changes that could be related to episodic mud breccia flows. From 148 mbsf down to the total logged depth (171.2 mbsf), a trend of increasing resistivity and sonic velocity (Figs. 5, 6) could reflect either other textural changes or sediment compaction features.

The resistivity values measured at Hole 971B (Figs. 5, 6) are much lower than those at Hole 970A (Figs. 2, 3). This can be related either to relatively higher clay content or to higher salinity of the pore waters.

\section{Sample Analysis}

The results of mineral composition analysis (Table 2; Fig. 5) are similar to those obtained for Unit II at the Milano mud volcano in Hole 970A. Significant proportions of halite were also detected; the pore waters are saturated with respect to halite in each of the holes drilled at Site 971 (Emeis, Robertson, Richter, et al., 1996). The clay 


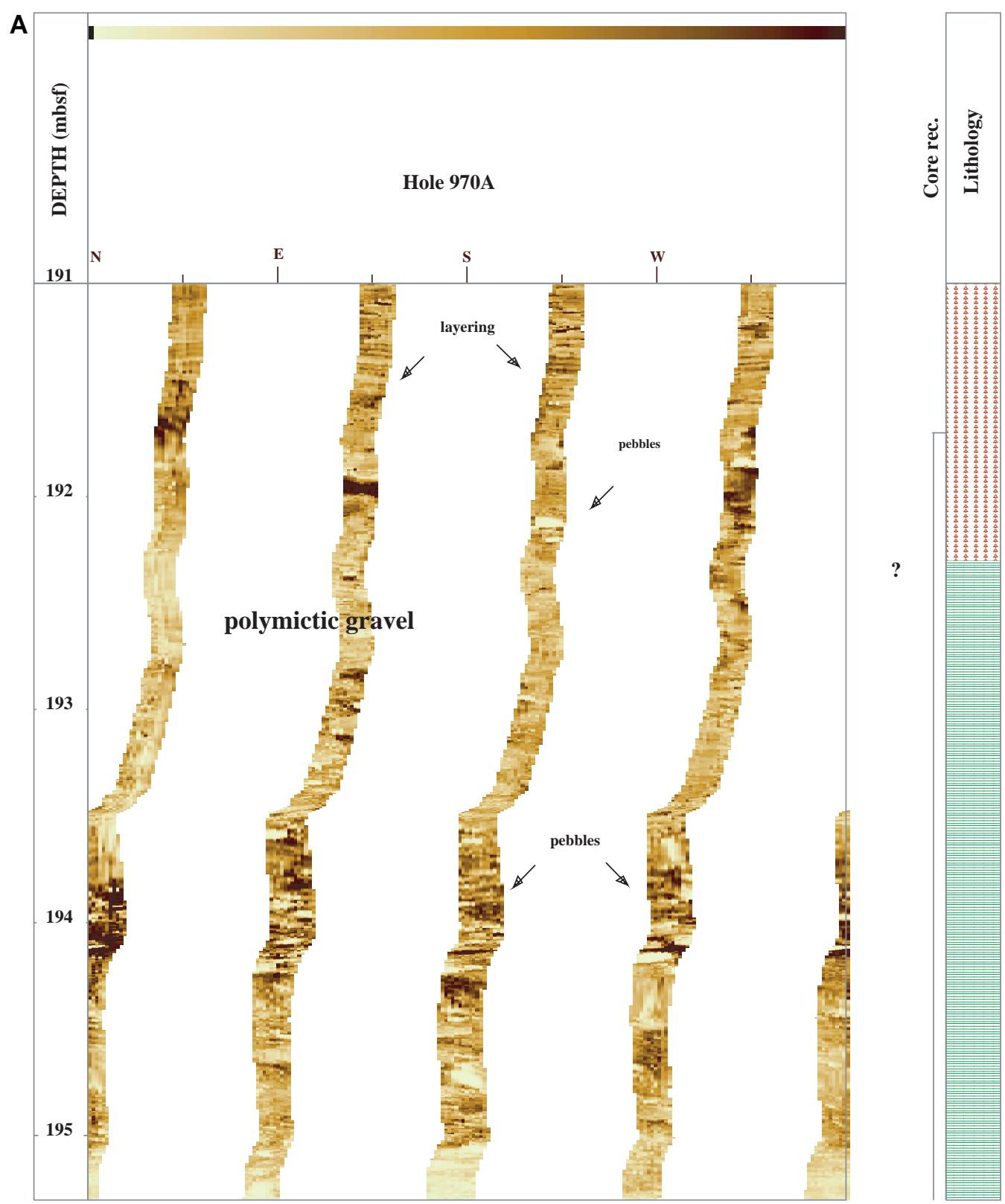

Figure 4. Hole 970A borehole wall FMS images $\left(0^{\circ}\right.$ to $\left.360^{\circ}\right)$. Static normalization enhanced images. Light color indicates higher resistivity. Vertical scaling results in flattening of features. A. Pebbly sediments of Unit II, larger size in the lower part of the polymictic gravel; layering in the upper part. Core recovery and lithostratigraphic column (Emeis, Robertson, Richter, et al., 1996) on the right-hand side. The boundary between the polymictic gravel and the nannofossil ooze indicated in the lithostratigraphic column does not correspond to the features recognizable on FMS images and is probably below the depth shown in the figure. (Continued next page.)

minerals are dominated by smectites (Table 3), showing the same composition as in Site 970 (i.e., Al-rich beidellites with fleecy morphologies). TEM analysis again indicates that the illite corresponds to detrital mica. Illite layers in the smectite (calculated according to Reynolds and Hower, 1970) yield low values at both volcanoes, and there is no evidence of increase in illite layers downhole or uphole, or any evidence of clay mineral diagenesis.

\section{FMS Interpretation}

The enhanced FMS images provide additional evidence of sedimentary layering and grading within the mud breccia. The base of the FMS logged interval (Fig. 7A) corresponds to a pebbly material.
"Ghosts" of pebbles can be recognized over intervals of poor pad contact. The presence of steeply dipping features $\left(>45^{\circ}\right)$ intersecting the hole could be interpreted as intersecting fractures (Figs. 6, 7). The strike of these steeply dipping planes varies from $340^{\circ}$ to $353^{\circ}$ and has been recognized at two different depth intervals between 74 and 102 mbsf (Figs. 7B, 7C; Table 4). Most of the steeply dipping planes appear on the FMS images as resistive features and show good contrast relative to the host sediment. This suggests either the presence of a resistive fluid (gas?) along these planes or a highly resistive material cementing the high-angle planes (could be halite).

A major difference detected relative to Hole 970A is that the dips of the planes, interpreted as sedimentary features, are rather steep (Fig. 6; Table 5). 
B

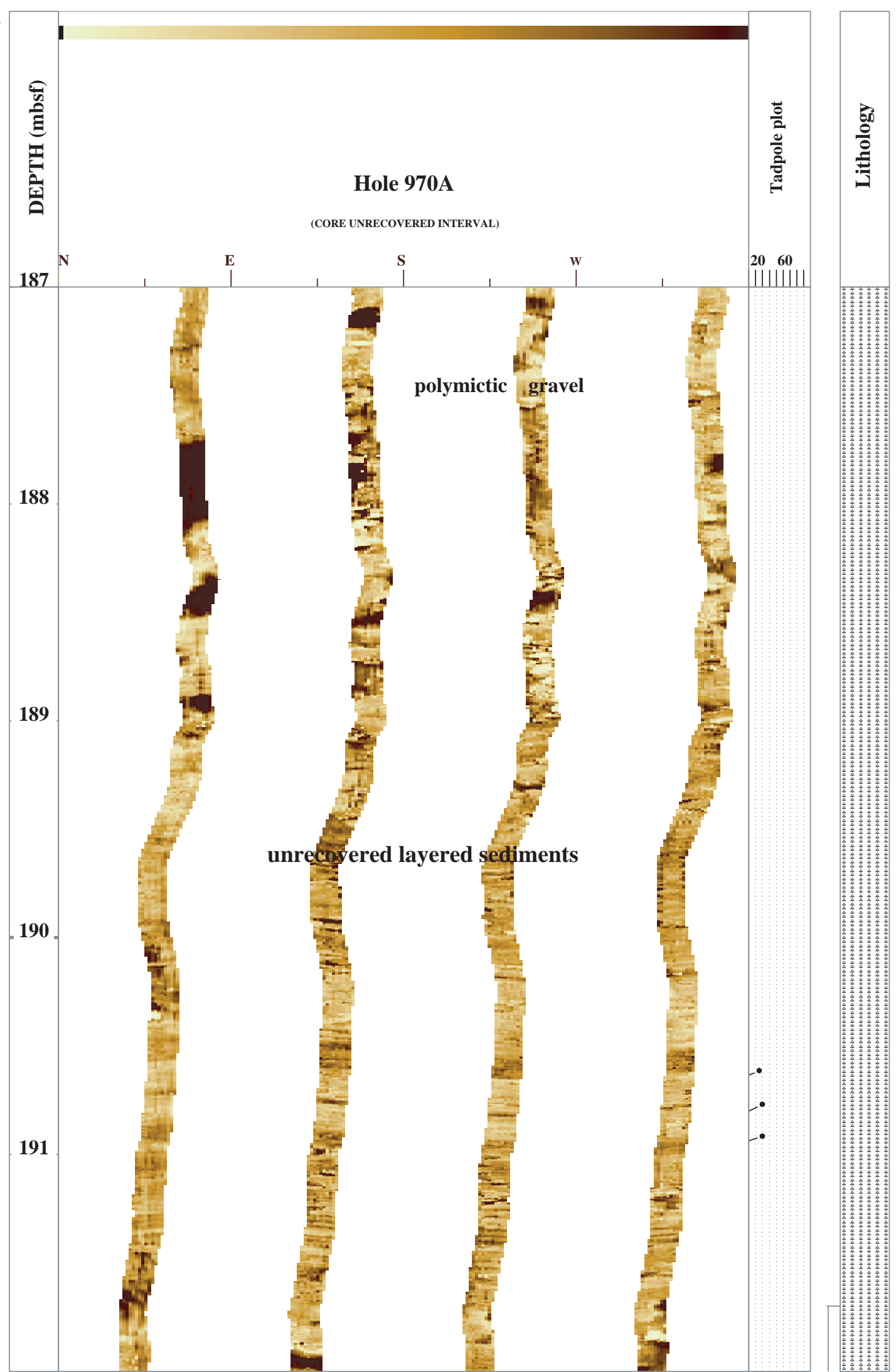

Figure 4 (continued). B. Layered sediments. The tadpole plot shows the dip of measured bedding planes; on the right-hand side, core recovery and lithostratigraphic column (Emeis, Robertson, Richter, et al., 1996). The depth interval shown in this image was not recovered. (Continued next page.) 


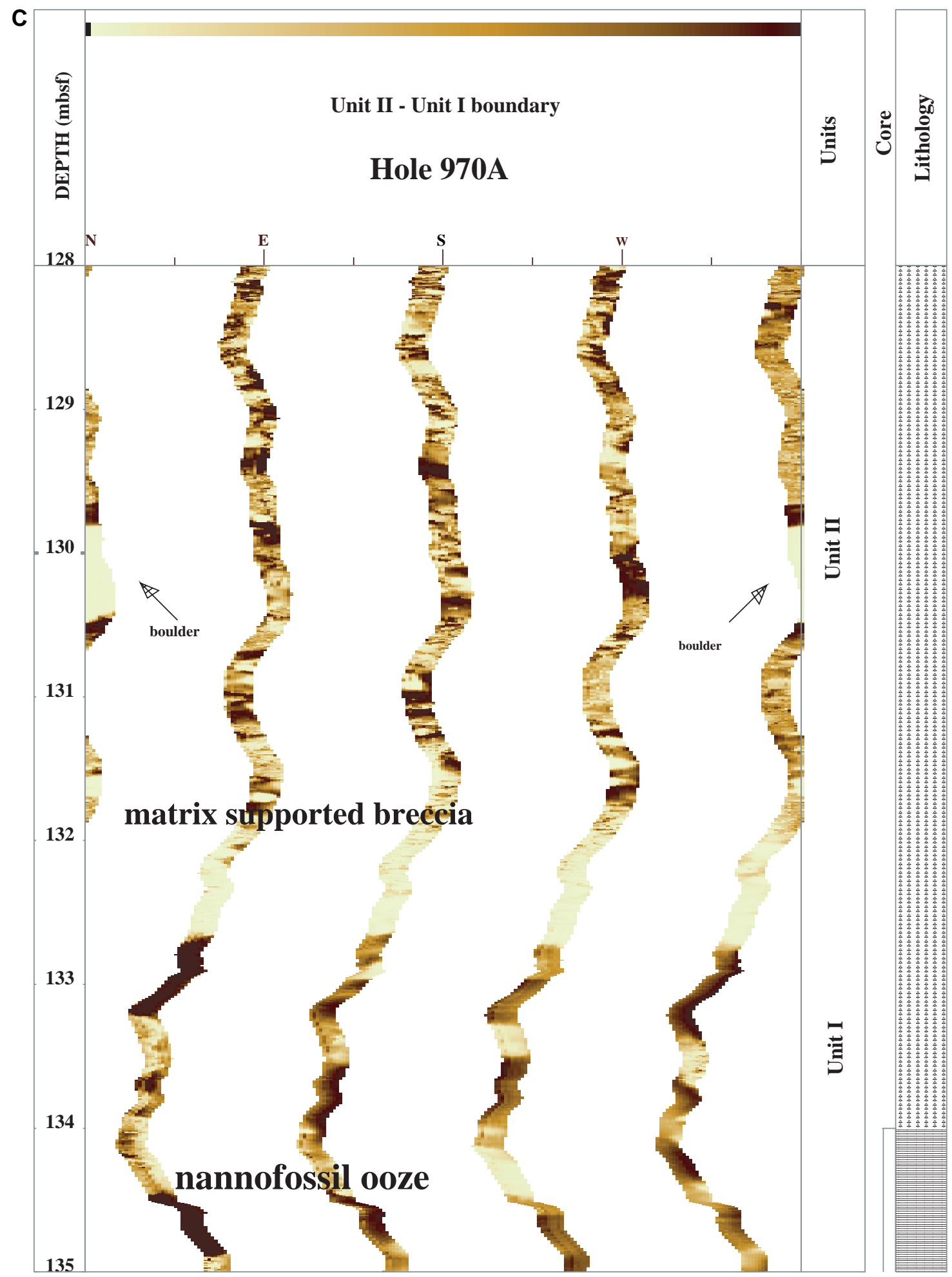

Figure 4 (continued). C. Boundary between Unit II (mud breccia, above) and Unit I (nannofossil ooze); core recovery and lithostratigraphic column (Emeis, Robertson, Richter, et al., 1996) on the right-hand side. The figure shows that the boundary between Unit II and Unit I could not be placed with precision because of the lack of core recovery. Close to the base of the Unit II mud breccia, a resistive boulder about $50 \mathrm{~cm}$ (130 mbsf) is seen on the image of pad 1 (left) and pad 4 (right) of pass 2 (it is also recognizable on pass 1 images). (Continued next page.) 


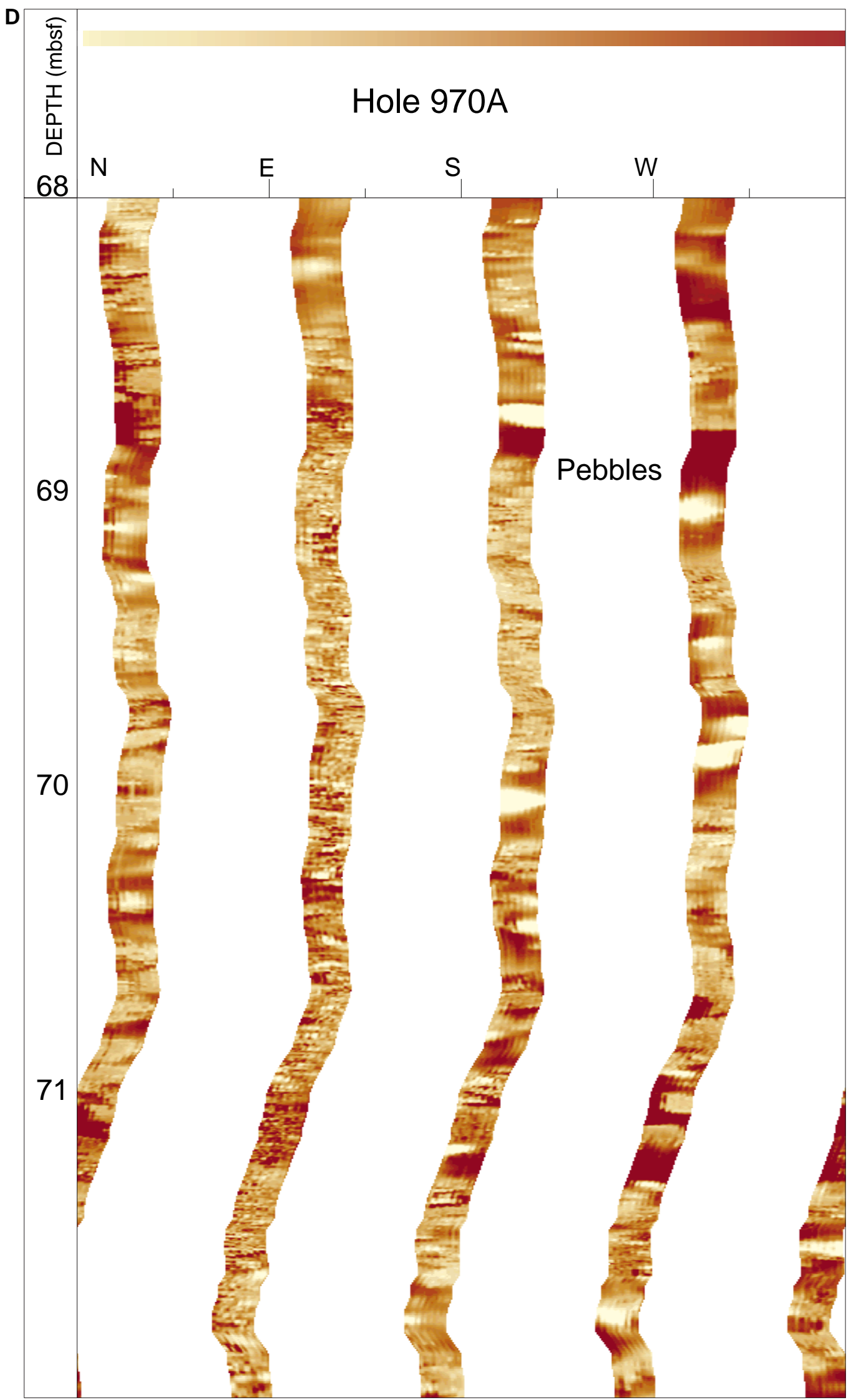

Figure 4 (continued). D. Mud breccia, upper part; subrounded pebbles. 
Figure 5. A. Conventional logs, Hole 971B: sonic log (SONI) in $\mu \mathrm{s} / \mathrm{ft}$, computed gamma-ray log (CGR) in API units, neutron $\log (\mathrm{TNPH})$ in porosity units, microspherically focused $\log$ (SFL) in $\Omega \mathrm{m}$, and deep induction resistivity $\log$ (ILD) in $\Omega \mathrm{m}$. B. Lithologic column. C. Core recovery. D. Sample analytical results for bulk and clay mineralogy: carbonate content (CALC), quartz (QTZ), clay minerals (PHYL), feldspar (FELD), kaolinite (KAOLI), micaceous minerals (ILLI), and smectites (SMEC).

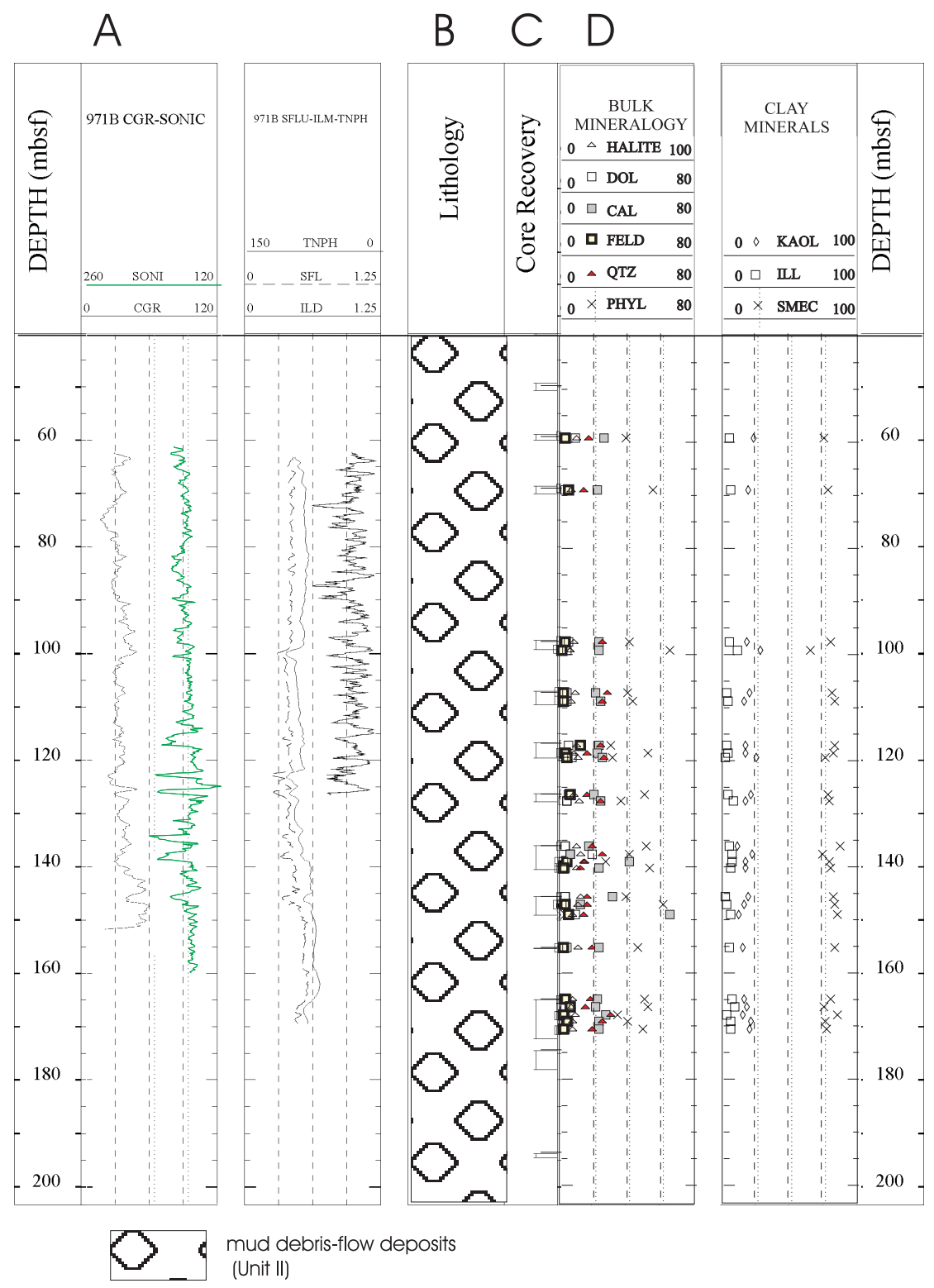

ed to explain the inward-dipping reflectors observed seismic sections (Emeis, Robertson, Richter, et al., 1996).

In the Napoli mud volcano all the measured planes dip towards the north (between east-northeast and west-northwest; Fig. 8), suggesting flow to the north. The strike of possible fractures is roughly aligned with stripes of high backscattering (possible lineations) identified at sea by Hieke et al. (1996; Fig. 8).

Mud volcanoes were constructed by piling up of semifluid debris flows, fed by a central vent. This episodic build-up is reflected in the $\log$ data. The clast-rich interval of the mud-debris flow material of Subunit II of Hole 971B was interpreted (Emeis, Robertson, Richter, et al., 1996) to reflect an early stage of extrusive activity (1.5-0.46 Ma). More homogeneous sediments with fewer clasts (Subunit IIB) were recovered at a higher stratigraphic level (older than $0.26 \mathrm{Ma}$ ). The compaction trends inferred from the conventional logs of the Napoli mud volcano are consistent with this interpretation.

The log response and sample analysis of the Milano and Napoli mud volcanoes (Figs. 2, 5, respectively), show that, for the same type 
A
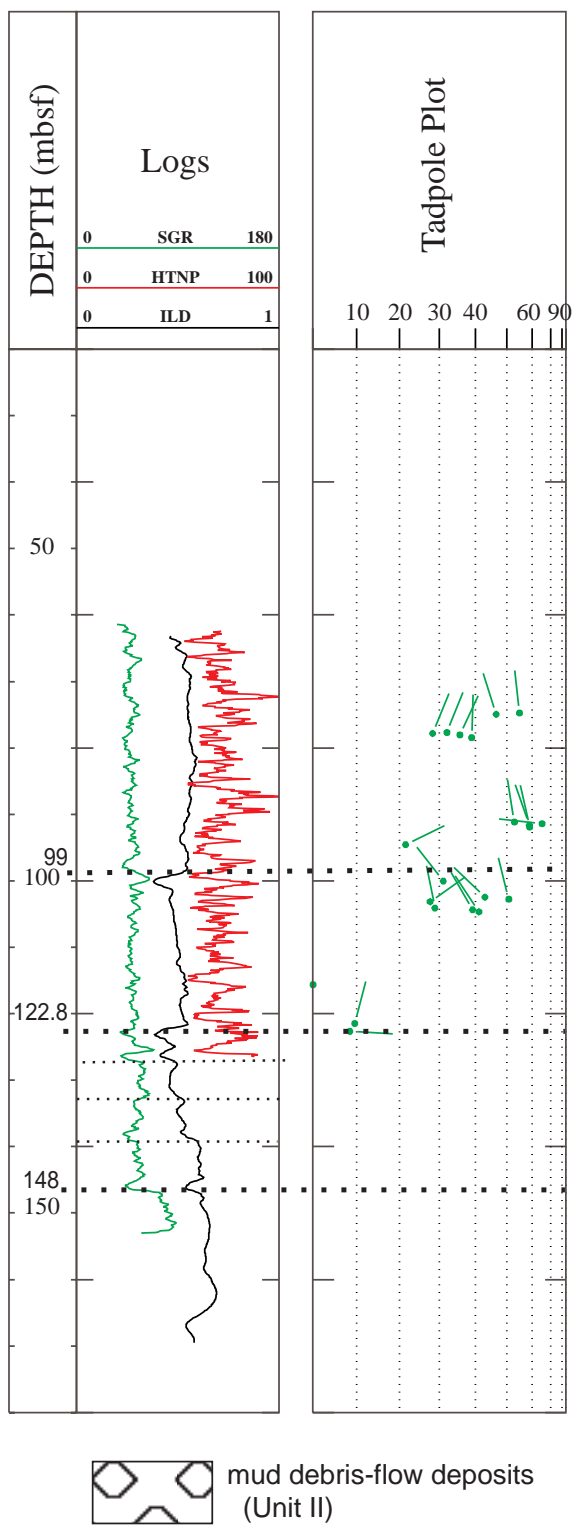

mud debris-flow deposits (Unit II)
C

ڤัٌ
D

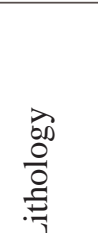

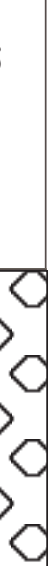

3
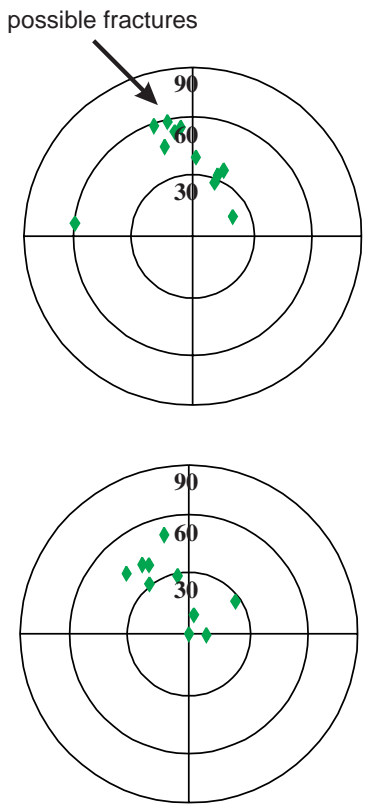

Figure 6. A. Conventional logs, Hole 971B: spectral total gamma radiation (SGR) in API units, neutron log (HTNP) in porosity units, and deep induction resistivity $\log$ (ILD) in $\Omega \mathrm{m}$. B. FMS-derived dips tadpole plot $\left({ }^{\circ}\right)$. C. Core recovery and core-reconstructed lithologic column. D. Schmidt projection of the interpreted dips, upper hemisphere. The dotted lines across the conventional logs indicate the depths at which changes in log values occur.

of matrix-supported, clast-rich, muddy debris-flow deposits, the electrical resistivity is higher at the Milano mud volcano. This can be explained by the effect of a relatively higher clay and lower carbonate content (Tables 1, 2) in Hole 971B. An alternative factor might be differences in salinity of the pore fluids (Emeis, Robertson, Richter, et al., 1996), saturation in $\mathrm{NaCl}$ in Hole 971B, as indicated by the presence of halite in samples.

The mud breccia and the layered fine sediments at the Milano mud volcano show different bulk mineral percentages. The smectite is significantly higher in both the mud breccia sediments of the Milano and of the Napoli mud volcanoes. In both types of sediments, clay minerals are mainly of detrital origin. Microanalytical data reveal that illites correspond to detrital micas and smectites correspond to Al-rich beidellites, which are also detrital in origin. Smectites resulting from reworking of soils developed under hydrolyzing conditions in poorly drained areas are mainly Al-Fe beidellites; whereas smectites richer in $\mathrm{Mg}$ are related to hydrothermal influence or in situ precipitation (Chamley, 1989). The smectite composition does not suggest, therefore, any connection to volcanic or hydrothermal processes, but supports instead a detrital supply. Palygorskite and sepiolite can be derived from reworking of subaerial environments where smectites could form by chemical precipitation within evaporative basins or pedogenetic crust (Chamley, 1989).

The higher smectite content in the matrix of the mud breccia sediments has some implications for provenance. Al-Fe beidellite is abundant in Messinian deposits (e.g., Chamley et al., 1977; Chamley et al., 1978; Chamley and Robert, 1980; Martínez-Ruiz et al., in press). This mineralogical feature is not observed outside the Mediterranean during the Messinian (e.g., Stein and Sarnthein, 1984). This suggests extensive soil development in circum-Mediterranean areas during the Messinian. The Messinian salinity crisis was associated with an increase in continental aridity, but short humid periods favored the development of smectite-rich soils (Chamley and Robert, 1980). Smectite percentages in the mud breccia matrix are comparable to those of Messinian smectite-rich sediments This suggests a Messinian source for these mud breccia matrix sediments. On the 
Table 5. Hole 971B: azimuth and dip of the planes interpreted on FMS images.

\begin{tabular}{|c|c|c|c|}
\hline \multirow[t]{2}{*}{$\begin{array}{l}\text { Hole 971B } \\
\text { Pass 1: }\end{array}$} & $\begin{array}{l}\text { Depth } \\
\text { (mbsf) }\end{array}$ & $\begin{array}{c}\text { Azimuth } \\
\left({ }^{\circ}\right)\end{array}$ & $\begin{array}{l}\text { Dip } \\
\left({ }^{\circ}\right)\end{array}$ \\
\hline & $\begin{array}{c}91.389 \\
94.57 \\
103.14\end{array}$ & $\begin{array}{l}275.8 \\
63.8 \\
55\end{array}$ & $\begin{array}{l}64.8 \\
21.5 \\
27.6\end{array}$ \\
\hline \multirow[t]{18}{*}{$\begin{array}{l}\text { Hole 971B } \\
\text { Pass 2: }\end{array}$} & $\begin{array}{l}\text { Depth } \\
\text { (mbsf) }\end{array}$ & $\begin{array}{c}\text { Azimuth } \\
\left({ }^{\circ}\right)\end{array}$ & $\begin{array}{l}\text { Dip } \\
\left({ }^{\circ}\right)\end{array}$ \\
\hline & 74.75 & 353.7 & 54.7 \\
\hline & 74.94 & 342.6 & 46.4 \\
\hline & 77.67 & 22.1 & 32 \\
\hline & 77.82 & 22.1 & 28.2 \\
\hline & 78.04 & 25 & 35.5 \\
\hline & 78.47 & 2.2 & 38.8 \\
\hline & 91.17 & 350.2 & 52.8 \\
\hline & 91.62 & 340.7 & 58.8 \\
\hline & 91.93 & 347.6 & 58.9 \\
\hline & 100.05 & 321.7 & 31 \\
\hline & 102.46 & 314.2 & 42.8 \\
\hline & 102.78 & 346 & 50.7 \\
\hline & 104.1 & 348.9 & 28.8 \\
\hline & 104.38 & 329.9 & 39.1 \\
\hline & 104.66 & 326.1 & 41 \\
\hline & 121.45 & 14.7 & 9.5 \\
\hline & 122.66 & 93 & 8.4 \\
\hline
\end{tabular}

other hand, the absence of diagenetic changes in the clay minerals is indicative of and absence of deep burial diagenesis.

\section{ACKNOWLEDGMENTS}

We thank Alastair Robertson and Michael Underwood for helpful reviews of the manuscript. Miriam Kastner is acknowledged for the use of analytical facilities at Scripps Institution of Oceanography, La Jolla, CA. The research of Jurado-Rodríguez was supported by a European Union HCM (ERB4001GT933623) grant and that of Martínez-Ruiz by a research grant of the Junta de Andalucía Research Group RNM-0179. The German ODP agency is acknowledged for providing postcruise meeting travel funds to the first author.

\section{REFERENCES}

Bourke, L.T., 1989. Recognizing artifact images on the Formation Microscanner. SPWLA 30th Ann. Logging Symp., pap. II: 1-25.

Caillère, S., Henin, S., and Rautureau, M, 1982. Minèralogie des Argiles, 2 : Classification et Nomenclature: Paris (Masson).

Camerlenghi, A., Cita, M.B., Della Vedova, B., Fusi, N., Mirabile, L., and Pellis, G., 1995. Geophysical evidence of mud diapirism on the Mediterranean Ridge accretionary complex. Mar. Geophys. Res., 17:115-141.

Chamley, H., 1989. Clay Sedimentology: Berlin (Springer-Verlag).

Chamley, H., Dunoyer de Segonzac, G., and Mélières, F., 1978. Clay minerals in Messinian sediments of the Mediterranean area. In Hsü, K.J., Montadert, L., et al., Init. Repts. DSDP, 42 (Pt. 1): Washington (U.S. Govt. Printing Office), 389-395.

Chamley, H., Giroud d'Argoud, G., and Robert, C., 1977. Genèse de semectites messiniennes de Sicile, implications paléoclimatiques. Geol. Mediterr., 4:371-378.

Chamley, H., and Robert, C., 1980. Sédimentation argileuse au Tertiaire supérieur dans le domain méditerranéen. Geol. Mediterr., 7:25-34

Cita, M.B., and Camerlenghi, A., 1992. The Mediterranean Ridge as an accretionary prism in collision context. Mem. Soc. Geol. Ital., 45:463480 .
Cita, M.B., Ivanov, M.K., and Woodside, J., 1996. The Mediterranean Ridge diapiric belt: introduction. Mar. Geol., 132:1-6.

Cita, M.B., Ryan, W.B.F., and Paggi, L., 1981. Prometheus mud-breccia: an example of shale diapirism in the Western Mediterranean Ridge. Ann. Geol. Pays Hellen., 30:543-570.

Ekstrom, M.P., Dahan, C., Chen, M.-Y., Lloyd, P., and Rossi, D.J., 1987. Formation imaging with microelectrical scanning arrays. Log Analyst, 28:294-306.

Emeis, K.-C., Robertson, A.H.F., Richter, C., et al., 1996. Proc. ODP, Init. Repts., 160: College Station, TX (Ocean Drilling Program).

Harker, S.D., McGann, G.J., Bourke, L.T., and Adams, J.T., 1990. Methodology of Formation Micro Scanner image interpretation in Claymore and Scapa Fields (North Sea). In Hurst, A., Lovell, M.A., and Morton, A.C. (Eds.), Geological Applications of Wireline Logs. Geol. Soc. Spec. Publ. London, 48:11-25

Hieke, W., Werner, F., and Schenke, H.W., 1996. Geomorphological study of an area with mud diapirs south of Crete (Mediterranean Ridge). Mar. Geol., 132:63-93.

Kisch, H.J., 1991. Illite crystallinity: recommendations on sample preparation, X-ray diffraction settings, and interlaboratory samples. J. Metamorph. Geol., 9:665-670.

Limonov, A.F., Woodside, J.M., and Ivanov, M.K. (Eds.), 1994. Mud Volcanism in the Mediterranean and Black Seas and Shallow Structure of the Eratosthenes Seamount. Initial Results of the Geological and Geophysical Investigations during the Third "Training-through-Research" Cruise of the R/V Gelendzhik (June-July 1993). UNESCO Rep. Mar. Sci., 64.

Lopez-Galindo, A, Fernadez-Segura, E, Sanchez-Navas, A, Martinez-Guerrero, M.J., and Ortega Huertas, M, 1989. Puesta a punto del microanálisis EDX con el Microscopio Electronico de Transmision Zeiss EM 10C. Rev. Soc. Geol. Esp., 2:153-159.

Martínez-Ruiz, F., Comas, M., and Alonso, B., in press. Mineral associations and geochemical patterns in sediments from the Alboran Basin: Sites 976 and 977. In Zahn, R., Comas, M., and Klaus, A. (Eds.), Proc. ODP, Sci. Results, 161: College Station, TX (Ocean Drilling Program).

Nieto, F., Ortega-Huertas, M., Peacor, D.R., and Arostegui, J., 1996. Evolution of the illite/smectite from early diagenesis through incipient metamorphism in sediments of the Basque-Cantabrian Basin. Clays Clay Miner, 44:304-326.

Reynolds, R.C., Jr., and Hower, J., 1970. The nature of interlayering in mixed-layer illite-montmorillonites. Clays Clay Miner., 18:25-36.

Rider, M., 1996. The Geological Interpretation of Well Logs: Caithness (Whittles Publishing).

Robertson, A., Emeis, K.-C., Richter, C., Blanc-Valleron, M.-M., Bouloubassi, I., Cramp, A., DeLange, G.J., DiStefano, E., Flecker, R., Frankel, E., Howell, M.W., Janecek, T.R., Jurado-Rodriguez, M.-J., Kemp, A.E.S., Koizumi, I., Kopf, A., Major, C.O., Mart, Y., Pribnow, D.F.C., Rabaute, A., Roberts, A., Rullkotter, J.H., Sakamoto, T., Spezzaferri, S., Staerker, T.S., Stoner, J.S., Whiting, B.M., and Woodside, J.M., 1996. Mud volcanism on the Mediterranean Ridge-Initial results of Ocean Drilling Program Leg 160. Geology, 24:239-242.

Schulz, H.M., Emeis, K.C., and Volkmann, N., 1997. Organic carbon provenance and maturity in the mud breccia from the Napoli mud volcano: indicators of origin and burial depth. Earth Planet. Sci. Lett., 144:141151.

Stein, R., and Sarnthein, M., 1984. Late Neogene oxygen-isotope stratigraphy and flux rates of terrigenous sediments at Hole 544B off Morocco. In Hinz, K., Winterer, E.L., et al., Init. Repts DSDP, 79: Washington (U.S. Govt. Printing Office), 385-394.

Date of initial receipt: 22 January 1997

Date of acceptance: 9 October 1997

Ms 160SR-043 
A

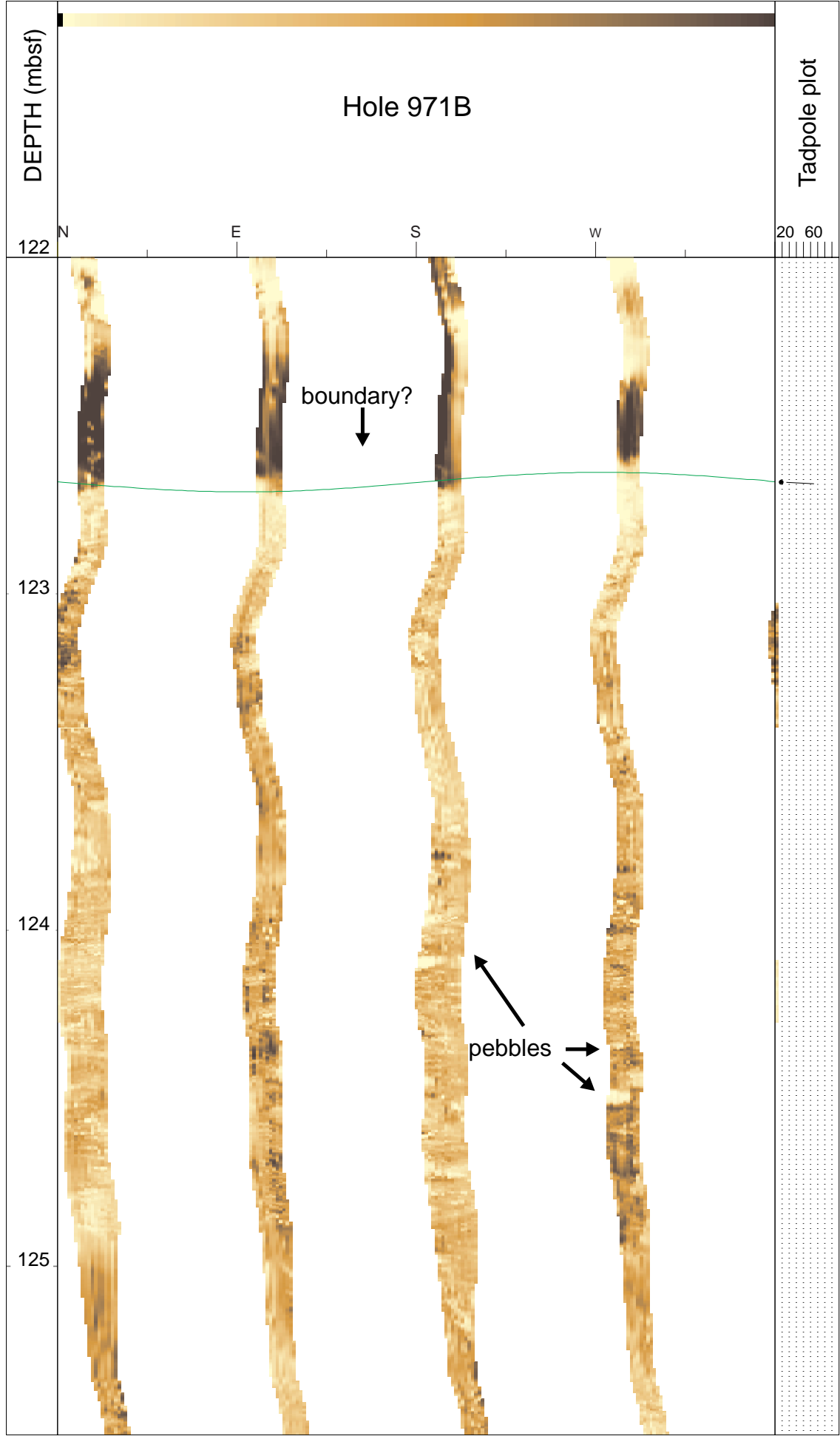

Figure 7. Borehole wall FMS images $\left(0^{\circ}\right.$ to $\left.360^{\circ}\right)$ : FMS static normalization enhanced images, Hole 971B. Light color indicates higher resistivity. Vertical scaling results in flattening of features. A. Shown at the bottom is the base of the logged interval; pebbly sediments, and a possible boundary surface in the upper part. The tadpole plot shows the dip of the interpreted planar features. (Continued next page.) 


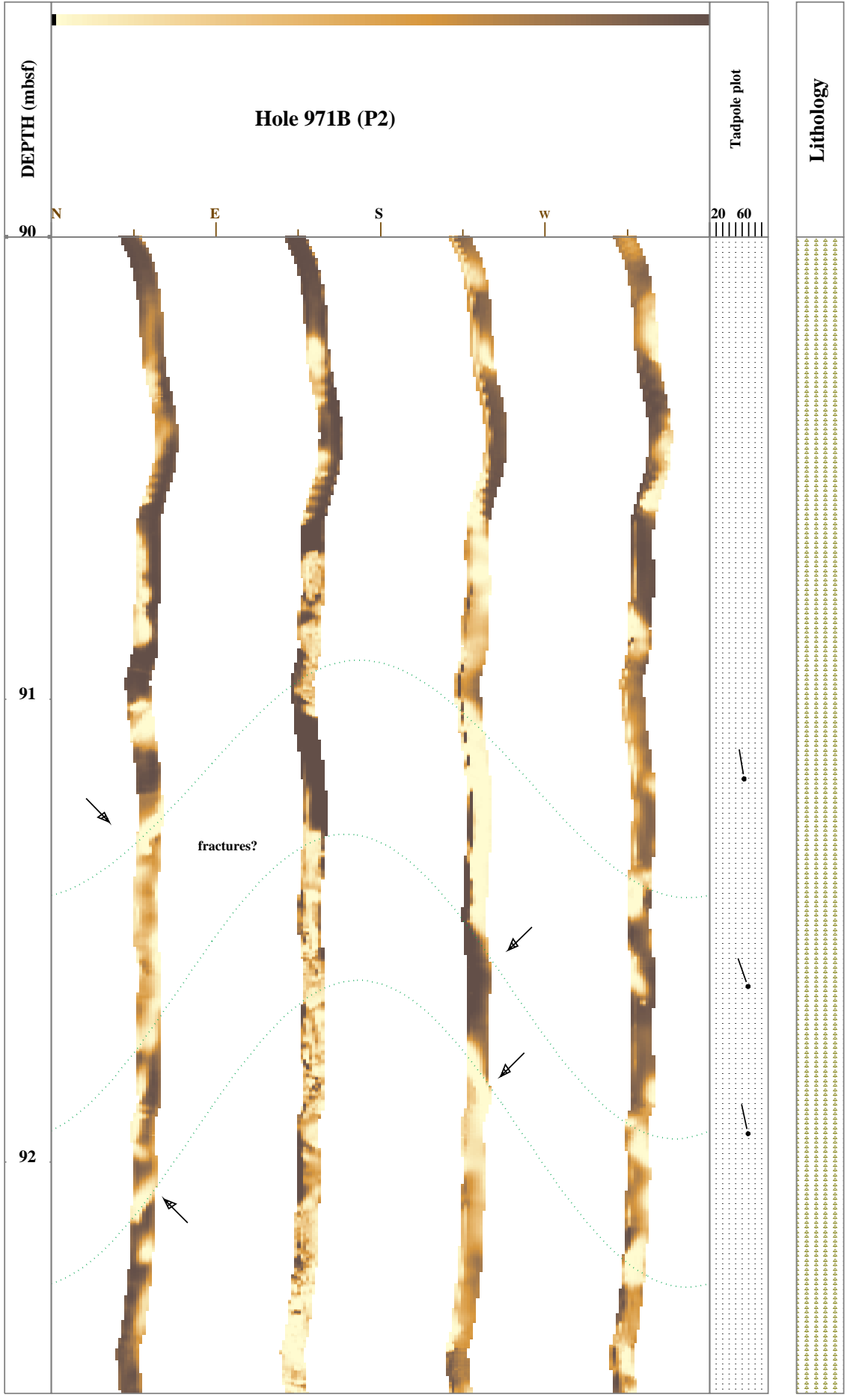

Figure 7 (continued). B, C. Steeply dipping highly resistive (light) planar features, possibly fractures. On the tadpole plot, the dip of the interpreted planar features and (on the right-hand side) lithology is represented for core-FMS images correlation (Emeis, Robertson, Richter, et al., 1996). (Continued next page.)

B 


$$
\text { III }
$$


MILANO MUD VOLCANO

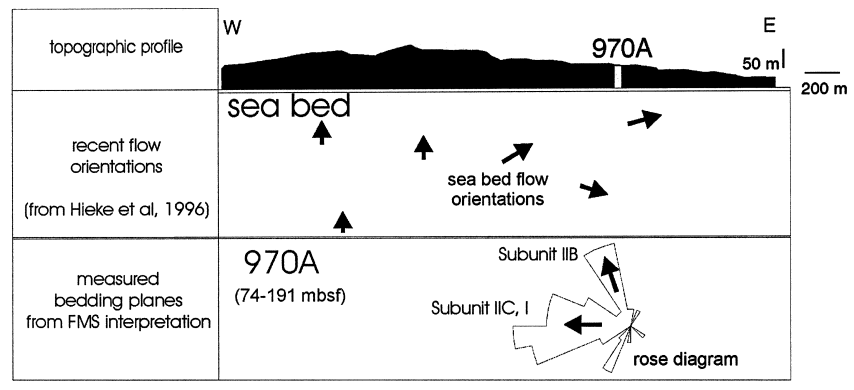

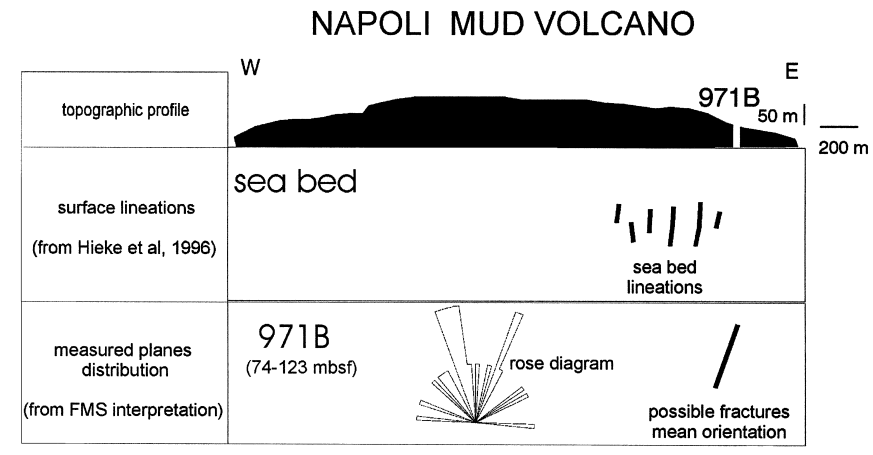

Figure 8. Sketch showing the interpretations on the internal geometry of the mud volcanoes on the basis of log interpretation results. The topographic profile and the surface features are from Hieke et al. (1996). 